\title{
Biogeographic comparisons of chemical and structural defenses of the Pacific gorgonians Annella mollis and A. reticulata
}

\author{
Melany P. Puglisi ${ }^{1, *}$, Valerie J. Paul ${ }^{3}$, Marc Slattery ${ }^{1,2}$ \\ ${ }^{1}$ Department of Pharmacognosy, and ${ }^{2}$ National Center for Natural Products Research, Research Institute of Pharmaceutical \\ Sciences, School of Pharmacy, The University of Mississippi, Mississippi 38677-1848, USA \\ ${ }^{3}$ University of Guam Marine Lab, Mangilao 96923, Guam
}

\begin{abstract}
Compared to other areas of chemical ecology, biogeographic comparisons of the chemical defenses associated with benthic marine organisms are few. This study addresses geographic differences in the chemical and structural defenses of 2 Pacific gorgonians (Annella mollis and A. reticulata), found at 2 islands: Guam, Micronesia, and Lizard Island, Australia. Crude extracts and sclerites extracted from the mid-axis and tips of colonies were assayed against natural assemblages of reef fishes at Western Shoals, Guam, and Mermaid's Cove, Lizard Island. Reciprocal feeding assays clearly demonstrated that crude extracts from Annella spp. were unpalatable to natural assemblages of reef fishes at Western Shoals and Mermaid's Cove and sclerites have little or no role as generalist predator defenses. Sclerites from the tips of A. reticulata were only effective as feeding deterrents at high concentrations. Variation in the palatability of the mid-axis extracts of $A$. mollis suggested that chemical defenses are more concentrated at the tips of the colonies from Guam and Lizard Island. When assayed at concentrations similar to and higher than the tips the mid-axis extracts did not deter fish feeding at Mermaid's Cove.
\end{abstract}

KEY WORDS: Biogeography · Chemical defenses · Marine chemical ecology · Annella mollis · Annella reticulata $\cdot$ Indo-pacific $\cdot$ Gorgonian

\section{INTRODUCTION}

Biogeographic comparisons of defenses in marine plants and invertebrates have evaluated qualitative and quantitative differences in secondary metabolites (Steinberg 1989, 1992, Targett et al. 1992, Harvell et al. 1993, Pavia \& Aberg 1996, Van Alstyne et al. 1999) or directly tested the responses of generalist consumers to organic extracts or plant materials (Van Alstyne \& Paul 1990, Bolser \& Hay 1996, Cronin et al. 1997, Pennings et al. in press). In comparisons between temperate and tropical species, higher levels of predator-deterrent compounds have been shown to be more common in tropical species (Bakus \& Green 1974, Bakus 1981,

*E-mail: mppuglisi@yahoo.com
Bolser \& Hay 1996), although there is evidence to suggest that this is not always the case (Steinberg 1992, Targett et al. 1992). The higher instance of defenses in marine organisms from tropical regions is proposed to be a consequence of increased predation and competition at lower latitudes (Bakus \& Green 1974, Bolser \& Hay 1996). This hypothesis is supported by comparisons made at the consumer level between temperate and tropical sea urchins and fish (Bolser \& Hay 1996, Cronin et al. 1997). Overall, consumers from North Carolina and the Bahamas preferred temperate algal species in paired assays when offered side-by-side with their congeners from the tropics (Bolser \& Hay 1996). In assays with sea urchins and fish from North Carolina and Guam, lower concentrations of pure metabolites from the brown alga Dictyota acutiloba were needed to deter the temperate herbivores com- 
pared to the tropical species (Cronin et al. 1997). Cronin et al. (1997) proposed that tropical herbivores (i.e. in Guam) are more resistant to seaweed chemical defenses.

Comparisons among species of brown algae from geographically different regions show that polyphenol (phlorotannins) concentrations can exhibit considerable latitudinal and local variation (Steinberg 1989, 1992, Steinberg \& Van Altena 1992, Pavia \& Aberg 1996, Van Alstyne et al. 1999). On the global scale, brown algae from Australia and New Zealand were shown to produce higher concentrations of polyphenols compared to their North American counterparts (Steinberg 1989, 1992). On the more local scale, Pavia \& Aberg (1996) reported considerable variability in polyphenol concentrations between 2 areas in the North Atlantic separated by $>1000 \mathrm{~km}$. Site-to-site comparisons in kelp and rockweeds along the north Pacific coast of the United States showed that only $25 \%$ of the kelps and 3 of 4 rockweeds exhibited geographic variation in polyphenol concentrations, suggesting that localized selection or phenotypic plasticity may be phylogenetically constrained (Van Alstyne et al. 1999). More recently, Pennings et al. (in press) addressed variability in herbivore defenses of marsh plants along the Atlantic coast of the USA with a variety of consumers. Reciprocal feeding assays clearly demonstrated that fresh marsh plant material from Rhode Island and Maine was more palatable to consumers from both northern and southern regions than plants from Florida and Georgia. Local variation of herbivore communities within temperate regions is suggested to select for these latitudinal trends (Steinberg 1992, Pennings et al. in press). Pavia \& Aberg (1996) point out the importance of local herbivores with a limited habitat range in explaining the differences in defenses between local communities. Early work on coral reefs suggested that almost all of the common, exposed coral reef invertebrates are chemically and/or structurally defended from predators (Bakus \& Green 1974, Green 1977, Bakus 1981). Because chemical and structural defenses are prevalent in tropical benthic marine organisms (Hay 1996) few studies have addressed local variation in defenses between tropical regions (Harvell et al. 1993) compared to tropical versus temperate and temperate versus temperate comparisons.

Gorgonian corals are conspicuous members of coral reef communities (Kinzie 1970, Yoshioka \& Yoshioka 1989). Except for a few specialist predators, coral reef fish and invertebrates do not readily consume sea fans and whips (Lasker 1985, Harvell \& Suchanek 1987, Lasker \& Coffroth 1988, Ruesink \& Harvell 1990, Van Alstyne \& Paul 1992, Vrolijk \& Targett 1992, Cronin et al. 1995, Slattery 1999). Gorgonians produce chemical (i.e. secondary metabolites) and/or structural (i.e. scle- rites) defenses against predation (Pawlik et al. 1987, Harvell et al. 1988, 1996, Fenical \& Pawlik 1991, Pawlik \& Fenical 1992, Van Alstyne \& Paul 1992, West $1997,1998)$. Some species exhibit intra-colony variation in secondary metabolite and sclerite concentrations suggesting that different parts of the colony rely more upon chemical defenses and others rely upon structural defenses (Harvell \& Fenical 1989, Van Alstyne \& Paul 1992). For example, the Caribbean gorgonians Pseudopterogorgia spp. have higher concentrations of metabolites at the tips of colonies and more sclerites in the base (Harvell et al. 1988, Harvell \& Fenical 1989). In other species, crude extract and sclerite concentrations are uniform throughout the colony (Van Alstyne \& Paul 1992, Slattery 1999). Gorgonia ventalina, also found in the Caribbean, exhibited no quantitative variation in crude extract and sclerite concentrations in the upper portions of the colony (Van Alstyne \& Paul 1992). However, Kim et al. (2000) have shown that crude extracts from the tips of healthy Gorgonia spp. colonies are more resistant to the fungal pathogen Aspergillus sydowii than extracts from other parts of the colony.

For some species, a variety of different secondary metabolites have been reported from colonies collected from discrete regions (Faulkner 1999 and references cited within). A geographic comparison of colonies of the Caribbean gorgonian Briareum asbestinum from the Bahamas and St. Croix showed that the 2 populations produced different classes of diterpenes as chemical defenses (Harvell et al. 1993). Further, in shallow habitats where colonies are exposed to higher levels of predation, B. asbestinum produced smaller sclerites at higher densities as structural defenses (West et al. 1993).

Biogeographic comparisons are thought to be essential to the understanding of the evolution and ecology of coral reef communities (Hay 1996, Sammarco 1996). In this study we address quantitative differences in crude extract and sclerite concentrations within colonies (base, mid-axis, tips) of 2 Pacific gorgonians, Annella mollis and A. reticulata, and among sites at 2 islands, Guam (GU) and Lizard Island (LI). We assay crude extracts and sclerites from the mid-axes and tips of the colonies against natural assemblages of reef fishes at: (1) their island of origin and (2) the other island. Previous studies of gorgonian corals on Caribbean reefs suggest that there is considerable variability in the production of chemical and structural defenses among species (Pawlik et al. 1987, Harvell \& Fenical 1989), making predictions of intra-colony variation in Annella spp. difficult. However, a broad survey of gorgonian crude extracts demonstrated that the extracts from species with small sclerites were usually unpalatable to fish (Pawlik et al. 1987, Harvell \& Fenical 1989). Small, colorless sclerites are characteristic of 
sea fans in the genus Annella (Chen \& Chang 1991); therefore we expected the crude extracts to be unpalatable to natural assemblages of reef fish. GU and LI are tropical, and predation should be intense at both islands (Hay 1996), suggesting that populations of Annella spp. will be under similar or equal pressure to produce defenses against generalist predators. This hypothesis predicts no differences in chemical and/or structural defenses among sites or between islands. Alternatively, local predators associated with different collection sites can result in differences in defenses (Pavia \& Aberg 1996).

\section{METHODS AND MATERIALS}

Study organisms. The Annella spp. (formerly Subergorgia spp., Family: Subergorgiidae) (Grassoff 1999) are azooxanthellate gorgonians common in the IndoPacific from the northern Red Sea to the central Pacific. They are the largest and most conspicuous sea fans on the reefs of GU, growing to $2-3 \mathrm{~m}$ at depths of $>20 \mathrm{~m}$. At LI, Annella spp. can be found on reefs as shallow as $5 \mathrm{~m}$ and at depths greater than $25 \mathrm{~m}$. Sea fans in this genus have branches closely anastomosed as a network. The sclerites are small and colorless (Chen \& Chang 1991). A. mollis (Nutting) is typically brown or orange with oblong cells. 'Double-wheel' sclerites characteristic of this species are found densely packed in the coenenchyme (Grassoff 1999). A. reticulata (Ellis \& Solander) is pink to orange with small cells characterized by 'double-head' sclerites. The larger, oblong cells of $A$. mollis and small cells of A. reticulata are often found in the same colony. In addition, the 'double-heads' and 'double-wheels' can be found in the same colony (Phil Alderslade pers. comm.). Colonies used in this study were identified by sclerite analysis and limited to those specimens that contained either the 'double-heads' or the 'double-wheels'.

Collection. Sea fans were collected by SCUBA from sites around GU $\left(144^{\circ} 45^{\prime} \mathrm{E}, 13^{\circ} 30^{\prime} \mathrm{N}\right)$ between March and July 1998 (Fig. 1) and sites around LI $\left(145^{\circ} 28^{\prime} \mathrm{E}\right.$, $14^{\circ} 41^{\prime} \mathrm{S}$ ) between January and February 1999 (Fig. 2). GU is a high island with fringing reefs. LI is a continental island on the Great Barrier Reef approximately $35 \mathrm{~km}$ off the coast of Queensland, Australia. Annella mollis was collected from Blue Hole, Cocos Wall and Hospital Point, GU, between 30 and $40 \mathrm{~m}$. Collections at LI were made at Mac Gillivray's Reef, North Point and Pidgin Point between 10 and $20 \mathrm{~m}$. A. reticulata was collected from the wall between the Blue Hole and Crevice and at Hospital Point, GU, between 30 and $40 \mathrm{~m}$, and from Bird Islets, Mac Gillivray's Reef and Pidgin Point, LI, between 10 and $15 \mathrm{~m}$. Voucher specimens were preserved in $70 \%$ ethanol or $10 \%$

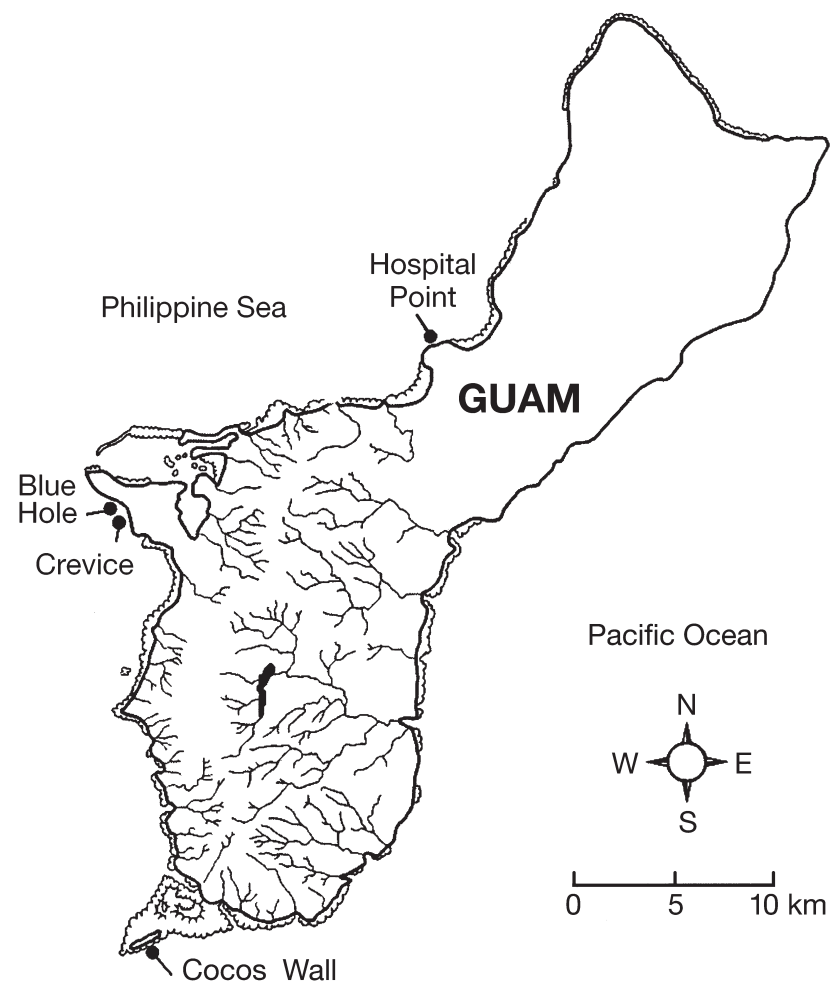

Fig. 1. Collection sites at Guam

formalin and air-dried depending upon what was available on site. A representative of each species was deposited in the collections at the University of Guam Marine Lab (UOGML), Museum and Art Gallery of the Northern Territories, Darwin, and/or Australian Museum of Natural History (all Australian samples), Sydney.

Between 2 and 6 individual colonies were removed from each site by cutting at the base of the sea fan with underwater shears. Colonies were separated into base (lowest $10 \mathrm{~cm}$ of colony), mid-axis (the center of the colony between the base and tip) and tip (top $5 \mathrm{~cm}$ of colony around the outer edges) sections (Harvell \& Fenical 1989, Van Alstyne \& Paul 1992). When possible, colonies were extracted immediately at the UOGML or LI Research Station (LIRS); otherwise, colonies were frozen at $0^{\circ} \mathrm{C}$ and freeze-dried for transport to the University of Mississippi, Oxford, or the University of New South Wales, Sydney, for extraction.

Crude extract, gorgonin and sclerite concentrations. A $3 \times 3 \mathrm{~cm}$ square piece of fresh or freeze-dried animal tissue was weighed and exhaustively extracted in 1:1 dichloromethane/methanol or 1:1 ethanol/ethyl acetate over $72 \mathrm{~h}$. The remaining tissue was dried in an oven for $24 \mathrm{~h}$ at $64^{\circ} \mathrm{C}$. After determining the dry mass, samples were dissolved in $5.25 \%$ sodium hypochlorite (bleach) solution to obtain the sclerites and the gor- 


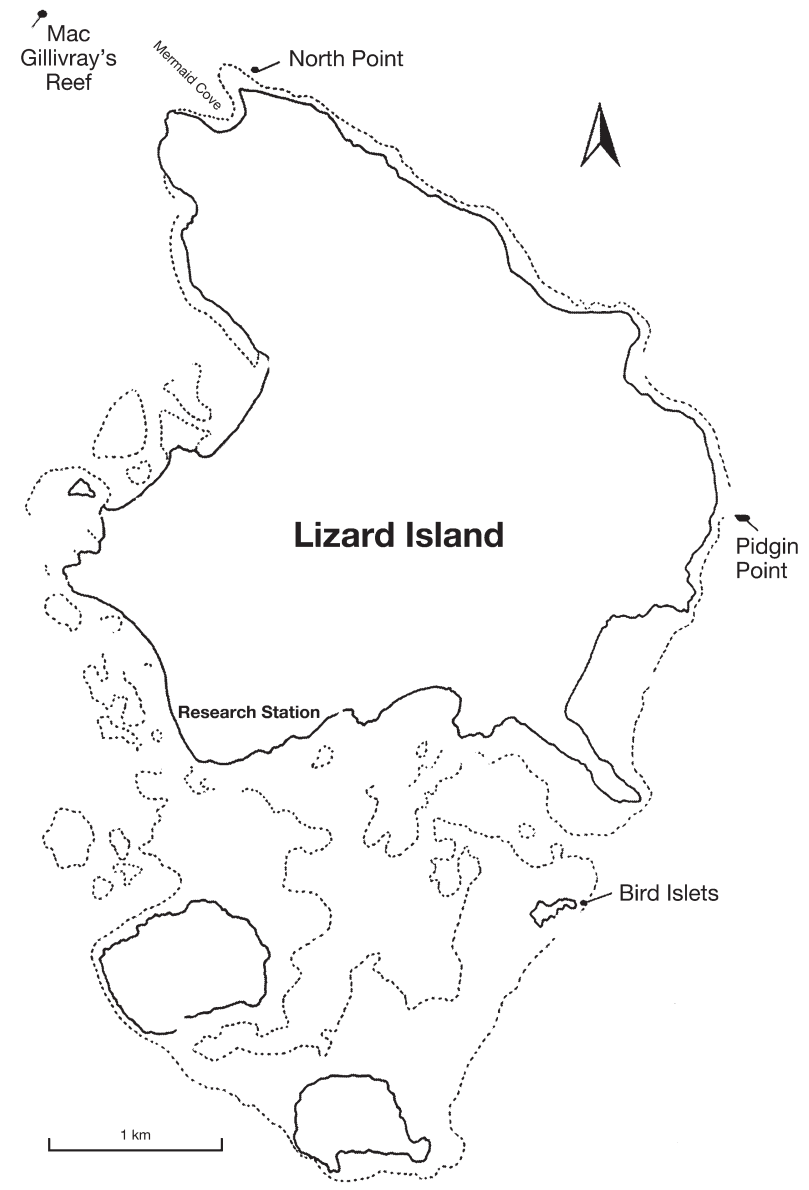

Fig. 2. Collection sites at Lizard Island

gonin skeleton. These were rinsed in fresh water and dried in an oven for $24 \mathrm{~h}$ at $64^{\circ} \mathrm{C}$. Crude extracts were dried down under reduced pressure (when available) and then weighed. All extracts were stored at $0^{\circ} \mathrm{C}$ and transported frozen to study sites. The concentration of sclerites was determined as a proportion of the entire colony (dividing by the total dry mass and multiplying by 100) and as a proportion of the soft tissue as described below for the crude extracts.

Yield $(\%)=\frac{\text { crude extract mass }}{(\text { dry mass }- \text { gorgonin skeleton mass })} \times 100$

Data did not meet the requirements for parametric analysis. Therefore, differences in base, mid-axis and tip yields among sites and within individuals were calculated with a 2-way Kruskal-Wallis test (Sokal \& Rohlf 1981). The factors were site and part of colony. Differences between the GU and LI populations were calculated by a Mann-Whitney $U$-test. Differences between sites were also calculated by a MannWhitney $U$-test with $\alpha$ adjusted for the number of analyses. In addition, the soft tissue concentrations of sclerites and crude extracts were compared by a simple regression to determine if there was a relationship between these variables. All statistical analyses were generated with Statview 5.0 for Macintosh (Abacus Concepts Inc.).

Protein concentration. The protein concentrations of the base, mid-axis and tips were determined by a modified Bradford protein assay (Slattery et al. 1995, Karentz et al. 1997). Approximately $50 \mathrm{mg}$ of tissue was removed from the gorgonin skeleton and digested for $12 \mathrm{~h}$ in $5 \mathrm{ml}$ of $1 \mathrm{~N} \mathrm{NaOH}$. Five $\mathrm{ml}$ of $1 \mathrm{~N} \mathrm{HCl}$ was added to neutralize the solution. Of each sample $200 \mu \mathrm{l}$ was diluted with $5 \mathrm{ml}$ of Bio-Rad protein solution and the absorbance ( $\lambda=595 \mathrm{~nm}$ ) was recorded on a DU-65 Beckman spectrophotometer. Protein concentrations were calculated with a calibration curve generated from standards with bovine serum albumin that were prepared following the same digestion procedure described above. Data did not meet the requirements for parametric analysis even after transformation. Differences in the protein concentration of base, mid-axis and tip among sites and within individuals were calculated with a 2-way Kruskal-Wallis test and post-hoc comparisons with a Mann-Whitney $U$-test as described above (Sokal \& Rohlf 1981). Mean protein concentration did not differ significantly among parts (base: $26.43 \pm 4.322$; mid-axis: $37.30 \pm 17.506$; tips $32.27 \pm$ $8.608) ;(p=0.0696)$ or among sites $(p=0.6862)$ for colonies of Annella mollis. There was a significant difference between the mean protein concentration of the base $(20.59 \pm 1.435)$ and the mean protein concentration of the mid-axis $(27.79 \pm 3.557)$ and tips $(27.02 \pm$ 4.909 ) in colonies of $A$. reticulata ( $p=0.0023$ ) but none among sites $(p=0.3323)$. The artificial diets were prepared to approximate the mean protein concentration of the mid-axes and tips of the colonies.

Feeding assays. Feeding experiments were conducted at Mermaid Cove, LI, in May 1999 and Western Shoals, GU, in June and July 1999. Enough material was available to test the crude extracts and sclerites from the mid-axes and tips, but not from the bases. Extracts and sclerites from the Annella mollis colonies collected from Hospital Point, GU, and Pidgin Point, LI, were selected for the feeding assay studies. We used extracts and sclerites from $A$. reticulata colonies collected at Blue Hole, GU, and Mac Gillivray's Reef, LI. To eliminate possible biases, the sources of the extracts and sclerites were chosen at random without prior knowledge of secondary metabolite composition.

Because we were unable to obtain the same diet at GU and LI we used 2 products that report similar nutritional qualities. In feeding assays conducted at GU, the artificial diet was prepared with $5.0 \mathrm{~g}$ Kruses ${ }^{\mathrm{TM}}$ Brand 
catfish food, $2.5 \mathrm{~g}$ carrageenan (Type 1) and $80 \mathrm{ml}$ water. In assays at LI, $5.0 \mathrm{~g}$ Atlantic Salmon Starter Crumbles was substituted for the catfish food and $3.75 \mathrm{~g}$ of carrageenan was added to adjust the protein concentration. The carrageenan was stirred into a $250 \mathrm{ml}$ beaker containing the water and microwaved on high until the mixture boiled, approximately 2 min. The fish food and extract (dissolved in ethyl acetate) or sclerites were stirred into the beaker after the carrageenan had cooled for approximately $30 \mathrm{~s}$. One $\mathrm{ml}$ of ethyl acetate was added to the control cubes for the crude extract assays. Twenty-five $1 \times 1 \mathrm{~cm}$ food cubes were prepared by pouring the mixture into a partitioned tray. At LI, the mixture was poured into a tray without partitions and $1 \times 1 \mathrm{~cm}$ cubes were cut with a wire.

A snorkeler or diver offered 1 control cube paired with 1 treatment cube to natural assemblages of fishes on the reef. The first cube that was completely eaten and not regurgitated within $15 \mathrm{~s}$ was scored as eaten and the other cube was scored as uneaten. This was usually very clear because the less palatable food cubes accumulated on the reef at the assay site. Fish were randomly offered food prepared with the crude extract from one part of the colony (mid-axis or tips) collected at GU or LI paired with a control. By testing the GU and LI extracts in the same assay, we eliminated any effects (i.e. learned aversion) due to the prior exposure which might occur if the fishes were exposed to one set of extracts before the other. We followed the same procedure for the sclerite assays. Only 2 sets of assays were conducted per day at a site. Data from the feeding assays were analyzed by a chi-square analysis for a $2 \times 2$ contingency table to compare the number of eaten and uneaten food cubes (Sokal \& Rohlf 1981).

An informal survey of the fish assemblages we encountered at Western Shoals, GU, and Mermaid's Cove, LI, suggests that there were considerable feeding guild differences. In feeding assays on GU we encountered schools of scissor-tail sergeant Abudefduf sexfasciatus, staghorn damsel Amblyglyphidodon curacao, juvenile parrotfishes Scarus schlegeli and S. sordidus, the occasional wrasses Cheilinus fasciatus and Thalossoma hardwickii, surgeonfishes Naso vlamengii, N. literatus and Acanthurus triostegus, and the butterflyfish Chaetodon auriga. At LI more species were present in fewer numbers during the assays. These included the butterflyfish C. citrinellis, C. lunula, C. vagabundus and $C$. unimaculatus, the angelfish Pomacentrus imperator and Centropyge flavissimus and the wrasses Cheilinus fasciatus, C. trilobatus, Epibulus insidiator, Heliochoeres trimaculatus, Thalossoma lutescens, T. purpurea and T. quinquevittatum. Also present were many species of damselfishes, goatfishes, and parrotfishes.

\section{RESULTS}

\section{Crude extract, gorgonin, and sclerite concentrations}

The gorgonin concentrations in colonies of Annella mollis and $A$. reticulata collected from sites around GU and LI were highest in the bases and decreased significantly ( $p<0.001$ ) approaching the tips (Table 1 ). Colonies of $A$. mollis did not exhibit differences in gorgonin concentrations among sites $(p=0.6019)$ or between islands $(p=0.4729)$. For $A$. reticulata, the overall gorgonin concentrations in the colonies collected from LI were significantly higher than from GU $(p=0.0166)$ but there were no significant differences among sites $(p=0.0618)$.

As a proportion of the whole colony dry mass, the sclerite concentrations (Table 1) were lowest in the bases and increased significantly $(\mathrm{p}<0.001)$ approaching the tips in colonies of both species. There were no differences among sites ( $p=0.1235)$ or between islands $(p=0.0648)$ in colonies of Annella mollis. Colonies of $A$. reticulata from GU had higher concentrations of sclerites than colonies from LI $(p=0.0166)$ but there were no significant differences among sites ( $\mathrm{p}=$ 0.0618).

Overall the sclerite and crude extract concentrations in the soft tissue (coenenchyme and polyps) of Annella mollis (Table 1a) were significantly higher in colonies collected from GU ( $p<0.001$ and $p=0.0164$, respectively), but there were no significant differences among parts ( $p=0.2053$ and $p=0.2813$, respectively). Colonies from Cocos Wall and Hospital Point, GU, had higher sclerite concentrations than the other 4 sites ( $p=0.0011$ ), and colonies from Hospital Point, GU, and Mac Gillivray's Reef, LI, had lower extract concentrations compared to the other 3 sites ( $p<0.001)$. There were no correlations between the soft tissue sclerite and extract concentrations for colonies from GU $\left(\mathrm{r}^{2}=\right.$ $0.008, \mathrm{p}=0.2711)$, LI $\left(\mathrm{r}^{2}=2.46 \times 10^{-4}, \mathrm{p}=0.9288\right)$ or the combined data set $\left(\mathrm{r}^{2}=0.021, \mathrm{p}=0.1251\right)$.

Soft tissue sclerite concentrations did not differ significantly among parts of Annella reticulata colonies $(\mathrm{p}=0.2254)$, collection sites $(\mathrm{p}=0.2144)$ or between islands ( $p=0.0783$ ) (Table $1 b)$. There were significant differences among sites $(p=0.0013)$ in crude extract concentration (Table $1 \mathrm{~b}$ ) but no overall significant difference among parts $(p=0.0779)$ or between the islands $(p=0.7102)$. Extract concentrations were higher at Hospital Point, GU, and Mac Gillivray's Reef, LI compared to the other 3 sites. This species also showed no correlation between the soft tissue sclerite and crude extract concentrations for colonies from GU $\left(\mathrm{r}^{2}=0.016, \mathrm{p}=0.5191\right)$, LI $\left(\mathrm{r}^{2}=0.021, \mathrm{p}=\right.$ $0.4246)$ or the combined data set $\left(\mathrm{r}^{2}=0.001, \mathrm{p}=\right.$ $0.7661)$. 
Table 1. Mean gorgonin, coenenchyme sclerite ${ }^{*}$, whole animal sclerite ${ }^{* *}$ and crude extract concentrations $(\%)$ with the standard error for the base, mid-axis and tips of (a) Annella mollis and (b) A. reticulata collected from Guam (GU) and Lizard Island (LI). $\mathrm{n}=$ number of colonies samples. $\mathrm{P}=$ part, $\mathrm{B}=$ base, $\mathrm{M}=$ mid-axis and $\mathrm{T}=$ tips

\begin{tabular}{|c|c|c|c|c|c|c|}
\hline Site & $\mathrm{n}$ & $\mathrm{P}$ & $\begin{array}{c}\text { Gorgonin } \\
\text { concentration (\%) }\end{array}$ & $\begin{array}{c}\text { Sclerite } \\
\text { concentration }(\%)^{*}\end{array}$ & $\begin{array}{c}\text { Sclerite } \\
\text { concentration }(\%)^{* *}\end{array}$ & $\begin{array}{c}\text { Crude extract } \\
\text { concentration }(\%)\end{array}$ \\
\hline \multicolumn{7}{|c|}{$\begin{array}{l}\text { (a) Annella mollis } \\
\text { GU }\end{array}$} \\
\hline Blue Hole & 3 & $\begin{array}{c}\mathrm{B} \\
\mathrm{M} \\
\mathrm{T}\end{array}$ & $\begin{array}{c}83.63 \pm 2.67 \\
70.63 \pm 4.92 \\
<1\end{array}$ & $\begin{array}{l}59.39 \pm 9.43 \\
74.48 \pm 0.47 \\
56.40 \pm 7.86\end{array}$ & $\begin{array}{r}9.97 \pm 2.92 \\
21.83 \pm 3.52 \\
56.40 \pm 7.86\end{array}$ & $\begin{array}{r}12.48 \pm 1.51 \\
9.71 \pm 0.19 \\
20.05 \pm 5.51\end{array}$ \\
\hline Cocos Wall & 5 & $\begin{array}{c}\mathrm{B} \\
\mathrm{M} \\
\mathrm{T}\end{array}$ & $\begin{array}{l}87.59 \pm 1.03 \\
74.14 \pm 4.79 \\
20.86 \pm 3.78\end{array}$ & $\begin{array}{l}66.31 \pm 5.45 \\
66.91 \pm 8.64 \\
75.49 \pm 4.57\end{array}$ & $\begin{array}{r}8.31 \pm 1.15 \\
17.38 \pm 4.12 \\
59.08 \pm 0.78\end{array}$ & $\begin{array}{l}15.59 \pm 1.86 \\
16.22 \pm 0.79 \\
31.80 \pm 5.07\end{array}$ \\
\hline $\begin{array}{l}\text { Hospital } \\
\text { Point }\end{array}$ & 3 & $\begin{array}{l}\mathrm{B} \\
\mathrm{M} \\
\mathrm{T}\end{array}$ & $\begin{array}{l}71.40 \pm 6.27 \\
52.63 \pm 12.90 \\
18.04 \pm 4.57\end{array}$ & $\begin{array}{l}86.17 \pm 6.89 \\
70.09 \pm 2.50 \\
70.03 \pm 5.66\end{array}$ & $\begin{array}{l}23.75 \pm 6.43 \\
33.21 \pm 9.08 \\
57.26 \pm 5.16\end{array}$ & $\begin{array}{r}10.81 \pm 4.92 \\
7.28 \pm 0.12 \\
6.71 \pm 1.08\end{array}$ \\
\hline $\begin{array}{l}\text { LI } \\
\text { Mac } \\
\text { Gillivray's } \\
\text { Reef }\end{array}$ & 5 & $\begin{array}{c}\mathrm{B} \\
\mathrm{M} \\
\mathrm{T}\end{array}$ & $\begin{array}{l}85.74 \pm 0.64 \\
73.89 \pm 3.21 \\
24.78 \pm 7.17\end{array}$ & $\begin{array}{l}43.73 \pm 5.95 \\
69.52 \pm 5.98 \\
72.41 \pm 7.42\end{array}$ & $\begin{array}{r}7.11 \pm 1.29 \\
20.32 \pm 5.44 \\
50.12 \pm 3.88\end{array}$ & $\begin{array}{l}4.63 \pm 0.41 \\
7.86 \pm 3.32 \\
5.23 \pm 2.01\end{array}$ \\
\hline North Point & 3 & $\begin{array}{c}\mathrm{B} \\
\mathrm{M} \\
\mathrm{T}\end{array}$ & $\begin{array}{l}82.69 \pm 1.79 \\
77.96 \pm 2.25 \\
26.27 \pm 2.51\end{array}$ & $\begin{array}{l}58.45 \pm 6.23 \\
59.90 \pm 16.11 \\
89.38 \pm 0.62\end{array}$ & $\begin{array}{r}10.15 \pm 1.46 \\
17.81 \pm 8.71 \\
74.3 \pm 3.10\end{array}$ & $\begin{array}{r}8.81 \pm 1.76 \\
9.35 \pm 1.34 \\
15.77 \pm 4.22\end{array}$ \\
\hline $\begin{array}{l}\text { Pidgin } \\
\text { Point }\end{array}$ & 4 & $\begin{array}{c}\mathrm{B} \\
\mathrm{M} \\
\mathrm{T}\end{array}$ & $\begin{array}{l}78.52 \pm 4.55 \\
77.56 \pm 4.63 \\
22.85 \pm 3.91\end{array}$ & $\begin{array}{l}26.23 \pm 4.57 \\
57.61 \pm 8.38 \\
33.41 \pm 12.25\end{array}$ & $\begin{array}{l}26.23 \pm 4.57 \\
13.22 \pm 2.56 \\
20.46 \pm 10.69\end{array}$ & $\begin{array}{l}11.21 \pm 3.25 \\
19.43 \pm 1.13 \\
13.72 \pm 4.10\end{array}$ \\
\hline \multicolumn{7}{|c|}{$\begin{array}{l}\text { (b) Annella reticulata } \\
\text { GU }\end{array}$} \\
\hline Blue Hole & 5 & $\begin{array}{c}\mathrm{B} \\
\mathrm{M} \\
\mathrm{T}\end{array}$ & $\begin{array}{r}87.52 \pm 1.65 \\
70.21 \pm 5.22 \\
6.38 \pm 1.97\end{array}$ & $\begin{array}{l}73.79 \pm 2.96 \\
71.26 \pm 2.03 \\
82.68 \pm 2.20\end{array}$ & $\begin{array}{r}9.23 \pm 1.34 \\
21.06 \pm 3.52 \\
78.18 \pm 3.39\end{array}$ & $\begin{array}{l}11.03 \pm 1.32 \\
10.24 \pm 1.59 \\
12.80 \pm 1.46\end{array}$ \\
\hline $\begin{array}{l}\text { Hospital } \\
\text { Point }\end{array}$ & 5 & $\begin{array}{c}\mathrm{B} \\
\mathrm{M} \\
\mathrm{T}\end{array}$ & $\begin{array}{l}85.16 \pm 3.06 \\
36.26 \pm 6.98 \\
10.91 \pm 2.49\end{array}$ & $\begin{array}{l}88.55 \pm 1.61 \\
83.91 \pm 3.88 \\
71.46 \pm 0.43\end{array}$ & $\begin{array}{l}24.42 \pm 3.36 \\
61.36 \pm 12.95 \\
62.64 \pm 8.06\end{array}$ & $\begin{array}{r}5.70 \pm 0.93 \\
3.39 \pm 0.21 \\
9.4 \pm 0.84\end{array}$ \\
\hline $\begin{array}{l}\text { LI } \\
\text { Bird Islets }\end{array}$ & 6 & $\begin{array}{c}\mathrm{B} \\
\mathrm{M} \\
\mathrm{T}\end{array}$ & $\begin{array}{l}85.66 \pm 0.64 \\
77.31 \pm 4.09 \\
21.04 \pm 3.28\end{array}$ & $\begin{array}{l}40.56 \pm 2.04 \\
54.86 \pm 3.72 \\
64.38 \pm 2.20\end{array}$ & $\begin{array}{r}5.53 \pm 0.56 \\
3.11 \pm 3.30 \\
50.63 \pm 1.58\end{array}$ & $\begin{array}{r}6.03 \pm 1.09 \\
13.52 \pm 2.91 \\
11.43 \pm 2.61\end{array}$ \\
\hline $\begin{array}{l}\text { Mac } \\
\text { Gillivray's } \\
\text { Reef }\end{array}$ & 2 & $\begin{array}{c}\mathrm{B} \\
\mathrm{M} \\
\mathrm{T}\end{array}$ & $\begin{array}{l}88.22 \pm 0.90 \\
81.29 \pm 1.33 \\
36.70 \pm 1.52\end{array}$ & $\begin{array}{l}37.63 \pm 0.78 \\
51.52 \pm 1.96 \\
48.94 \pm 6.15\end{array}$ & $\begin{array}{r}4.42 \pm 0.24 \\
9.78 \pm 1.07 \\
31.13 \pm 4.65\end{array}$ & $\begin{array}{l}5.14 \pm 0.40 \\
3.67 \pm 2.21 \\
8.64 \pm 1.92\end{array}$ \\
\hline $\begin{array}{l}\text { Pidgin } \\
\text { Point }\end{array}$ & 3 & $\begin{array}{l}\mathrm{B} \\
\mathrm{M} \\
\mathrm{T}\end{array}$ & $\begin{aligned} 84.8 & \pm 2.51 \\
74.94 & \pm 2.06 \\
42.31 & \pm 17.52\end{aligned}$ & $\begin{array}{l}32.30 \pm 0.66 \\
53.68 \pm 2.93 \\
45.59 \pm 1.66\end{array}$ & $\begin{array}{r}5.11 \pm 0.71 \\
13.56 \pm 1.62 \\
38.40 \pm 4.34\end{array}$ & $\begin{array}{l}10.61 \pm 1.04 \\
11.87 \pm 0.87 \\
14.53 \pm 7.91\end{array}$ \\
\hline
\end{tabular}

\section{Feeding assays}

The crude extracts from the mid-axes and tips of Annella mollis colonies deterred feeding by natural assemblages of fishes at Western Shoals and Mermaid's Cove ( $p<0.001$ ) with 2 exceptions (Fig. 3a,c). The mid-axis extracts from GU and LI were not unpalatable to fish at Mermaid's Cove $(p=0.2037$ and $p=$ 0.4056, respectively). Sclerites do not appear to serve as structural defenses for this species (Fig. 3b,d).
Crude extracts from the mid-axes and tips of Annella reticulata colonies deterred feeding by fish $(p<0.001)$ (Fig. 4a,c), and some evidence suggests that sclerites can deter predators at high concentrations $(\mathrm{p}<0.001)$ (Fig. 4b,d). At Western Shoals, the LI mid-axis extract was palatable to reef fish ( $\mathrm{p}=0.1524)$ (Fig. 4a). Sclerites from the tips of $A$. reticulata from GU deterred feeding at Western Shoals $(p=0.05)$ and Mermaid's Cove $(p<0.001)$ when incorporated into the diet at $78.18 \%$ (Fig. 4d). Low concentrations of sclerites from the tips of 

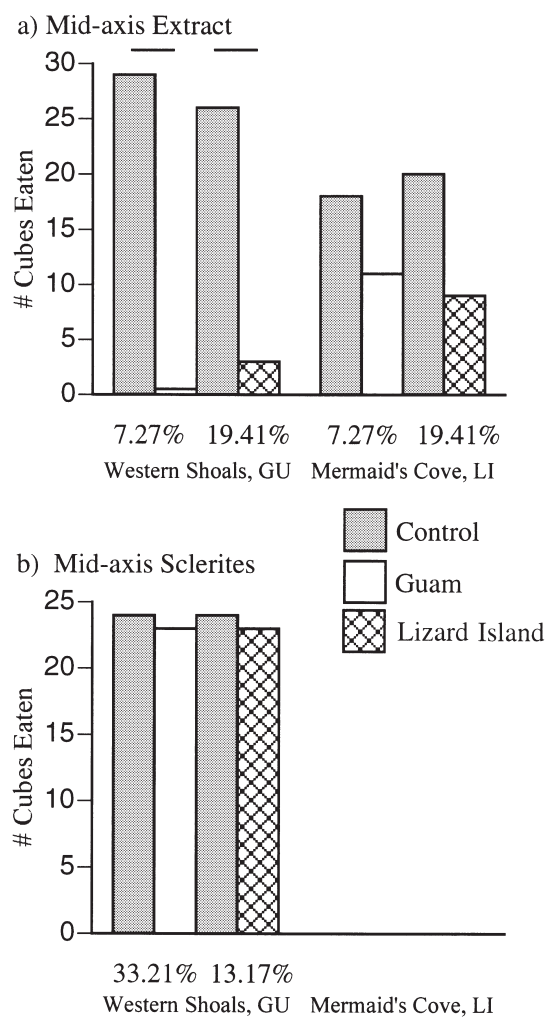

Fig. 4. Feeding assay results for (a) mid-axis crude extracts $(\mathrm{n}=20)$ and (b) sclerites $(\mathrm{n}=28)$, and (c) tip crude extracts $(\mathrm{n}=22)$ and $(\mathrm{d})$ sclerites $(\mathrm{n}=20)$ from Annella reticulata collected from Blue Hole, GU, and Mac Gillivray's Reef, LI. Crude extract and sclerite concentrations are indicated below each bar. A significant difference $(p<0.05)$ between the palatability of the control and treated cubes is indicated by a line drawn above the 2 corresponding bars. A line drawn above the 4 corresponding bars indicates a significant difference between the palatability of the GU and LI extracts or sclerites. $\mathrm{n}=$ number of replicate pairs in each assay

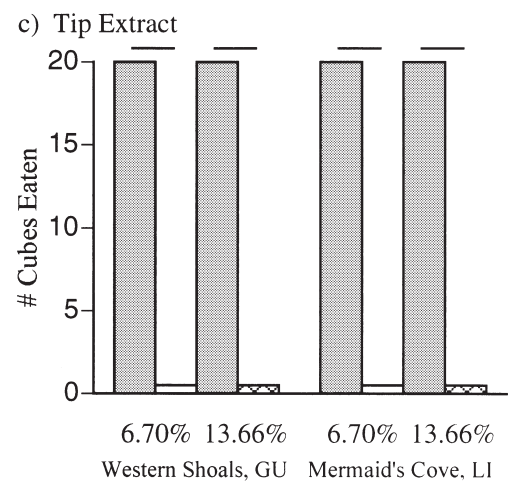

d) Tip Sclerites

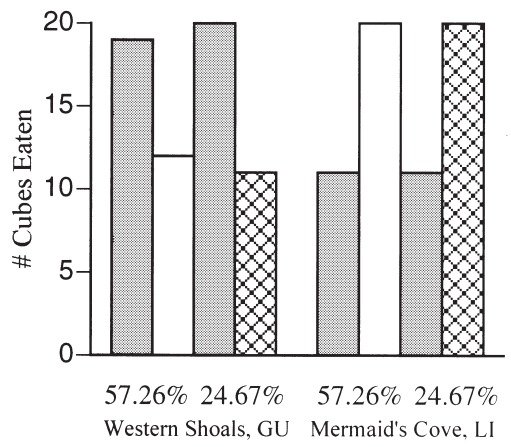

Fig. 3. Feeding assay results for (a) midaxis crude extracts $(n=29)$ and $(b)$ sclerites $(\mathrm{n}=47)$, and (c) tip crude extracts $(\mathrm{n}=20)$ and $(\mathrm{d})$ sclerites $(\mathrm{n}=31)$ from $A n$ nella mollis collected at Pidgin Point, Lizard Island (LI) and Hospital Point, Guam (GU). Crude extract and sclerite concentrations are indicated below each bar. A significant difference $(p<0.05)$ between the palatability of the control and treated cubes is indicated by a line drawn above the 2 corresponding bars. $\mathrm{n}=$ number of replicate pairs in each assay
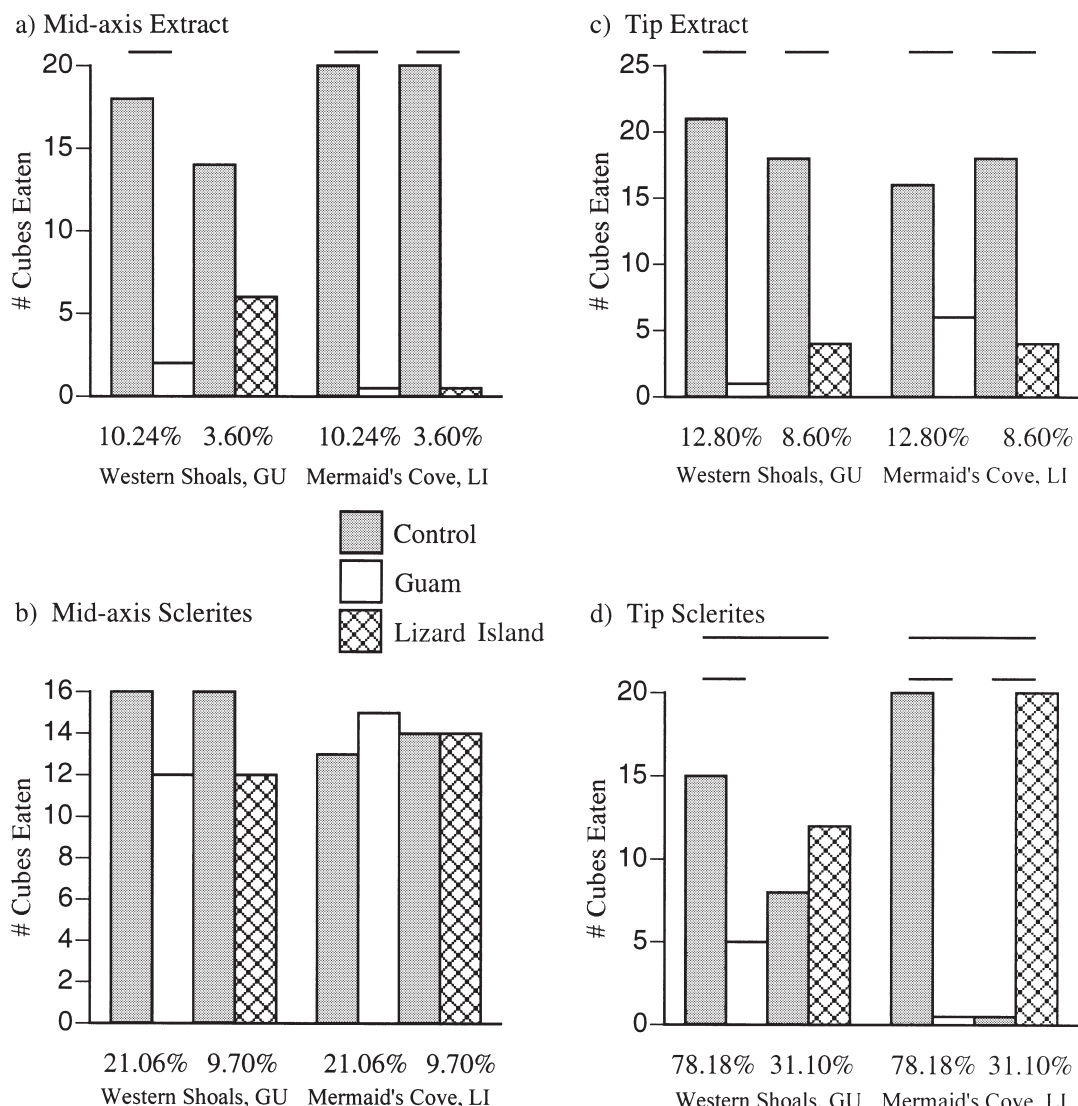
A. reticulata colonies collected at LI were preferred over the control cubes at Mermaid's Cove $(p<0.001)$.

\section{DISCUSSION}

The reciprocal feeding assays conducted in this study clearly show that the crude extracts from Annella mollis and $A$. reticulata are unpalatable to natural assemblages of reef fishes at Western Shoals and Mermaid's Cove (Figs. $3 \& 4$ ). Sclerites from some Caribbean species have been shown to be unpalatable to fish when incorporated into artificial diets at high concentrations (Harvell et al. 1988, Van Alstyne \& Paul 1992, West 1998, Slattery 1999). We observed similar results for sclerites from the tips of $A$. reticulata. These were only effective feeding deterrents at Western Shoals and Mermaid's Cove when assayed at $78.18 \%$ (Fig. 4d). In fact, at $31.10 \%$, sclerites from the tips of $A$. reticulata collected at LI were preferred over the control cubes by fish at Mermaid's Cove. While some species, such as Gorgonia ventalina, invest in the production of chemical and structural defenses (Van Alstyne \& Paul 1992, Slattery 1999), gorgonians in the genus Annella specialize in the production of chemical defenses against generalist predators (Harvell \& Fenical 1989).

Unlike the tip extracts, the mid-axis extracts from $\mathrm{An}$ nella mollis and $A$. reticulata did not always deter feeding by natural assemblages of fishes. The mid-axis extracts of A. mollis from GU and LI did not deter fish feeding at Mermaid's Cove when assayed at concentrations similar to and higher than the tip extracts. These results suggest that the chemical defenses of $A$. mollis are more concentrated at the tips of the colonies. Similar patterns of intracolony variation have been reported for the Caribbean gorgonians Pseudopterogorgia rigida (Harvell et al. 1988, Harvell \& Fenical 1989) and Gorgonia spp. (Kim et al. 2000). Higher concentrations of predator-deterrent secondary metabolites were found at the tips of P. rigida colonies (Harvell et al. 1988, Harvell \& Fenical 1989). Crude extracts from the colony edges of Gorgonia spp. exhibited greater fungal resistance against the pathogen Aspergillus sydowii (Kim et al. 2000). It is not surprising to find the tips of the colonies better defended against generalist predators. Optimal defense theory would predict that chemical defenses would be greatest in new growth. This pattern has been observed for many marine organisms (Paul \& Van Alstyne 1988, Harvell \& Fenical 1989, Van Alstyne et al. 1994, Becerro et al. 1998, Kim et al. 2000). During vegetative reproduction new polyps are added to the outer colony edges (Szmant-Froelich 1974).

In feeding assays at Mermaid's Cove, the mid-axis extracts of Annella reticulata from LI and GU were both unpalatable to reef fishes (Fig. 4a), but at Western
Shoals the LI extract did not deter fish feeding. The natural concentration of the mid-axis extract from GU $(10.24 \%)$ was approximately 3 -fold higher than the natural concentration of the LI mid-axis extract $(3.60 \%)$. The results of these assays suggest that fishes in GU may have a higher tolerance to the mid-axis extracts at low concentrations. Since we used different diets in the feeding assays at Western Shoals and Mermaid's Cove we were not able to make direct comparisons between the results from the feeding assays at the 2 sites.

Differences in fish assemblages between the islands may account for some of the variability seen in the palatability of the mid-axis extracts for both Annella mollis and A. reticulata (Pavia \& Aberg 1996). The Indo-Pacific, Indonesia and the Great Barrier Reef host a greater diversity of coral reef fishes (Thresher 1991). Informal surveys of the fish assemblages we encountered at Wester Shoals and Mermaid's Cove suggest that there were considerable feeding guild differences. On GU we mainly encountered schools of Abudefduf sexfasciatus, Amblyglyphidodon curacao, juvenile parrotfishes and the occasional wrasses, surgeonfishes and butterflyfishes. At LI more species were present in fewer numbers during the assays, including several species of butterflyfishes, angelfishes, wrasses, damselfishes, goatfishes, and parrotfishes.

Overall, the crude extract concentrations in the Annella mollis from GU were significantly higher than in colonies from LI (Table 1a). The natural concentrations of extracts collected at some sites around LI were approximately $1 / 2$ of those in the colonies from GU. And, crude extract concentrations did vary among sites at both islands for colonies of $A$. reticulata (Table $1 \mathrm{~b}$ ). However, palatability of the extracts does not appear to be highly correlated with crude extract concentration.

The Annella spp. had fairly consistent sclerite and crude extract concentrations in the soft tissue throughout the colony (Table 1). In this respect, A. mollis and A. reticulata are similar to the Caribbean gorgonian Gorgonia ventalina (Van Alstyne \& Paul 1992, Cronin et al. 1995, Slattery 1999) but not the Pseudopterogorgia spp. (Harvell \& Fenical 1989). Colonies of Pseudopterogorgia spp. exhibited an inverse relationship in crude extract and sclerite concentrations, where sclerite concentrations increased from tips to bases. We did not observe any correlation between the crude extract and sclerite concentrations for $A$. mollis or A. reticulata. Sclerites in cnidarians and spicules in other phyla, when densely packed, have been shown to increase rigidity and resist excessive deformation and tearing that could result from environmental stresses such as heavy currents (Koehl 1982, Lewis \& Von Wallis 1991, West et al. 1993). In the basic architecture of Annella spp., the gorgonin skeleton com- 
prised up to $90 \%$ of the dry mass at the bases but less than $1 \%$ of the total dry mass in the tips, while sclerites could comprise more than $70 \%$ of the dry mass at the tips (Table 1). A major role of sclerites in Annella spp. is probably the support of new tissues at the tips before an internal gorgonin skeleton can be deposited (Szmant-Froelich 1974).

Compared to other areas of chemical ecology, biogeographic comparisons of the predator/herbivore defenses associated with benthic marine organisms are few, mainly addressing differences between tropical and temperate species (Hay 1996, Sammarco 1996). This is the first study to address geographic differences in the palatability of crude extracts and sclerites of gorgonians collected from 2 distant tropical islands in the Pacific Ocean. The feeding experiments clearly demonstrated that Annella mollis and A. reticulata from GU and LI are chemically rather than structurally defended against natural assemblages of coral reef fishes, thus supporting the hypothesis that extracts from species with small sclerites are usually unpalatable to fish (Pawlik et al. 1987, Harvell \& Fenical 1989). With a few exceptions, the crude extracts from the mid-axes and tips of both species collected from GU and LI were unpalatable to fishes at both Western Shoals and Mermaid's Cove. The production of chemical defenses by Annella spp. appears to be ubiquitous over a broad range in the Pacific. In other geographic comparisons of predator defenses in octocorals, the production of chemical defenses was reported to be highly conserved (Coll \& Sammarco 1988). Harvell et al. (1993) also demonstrated that, while colonies of Briareum asbestinum from the Bahamas and St. Croix are both chemically defended against predation (Pawlik et al. 1987), the 2 populations produced different classes of secondary metabolites. Further studies are needed to determine if $A$. mollis and $A$. reticulata from GU and LI produce similar predator-deterrent compounds.

Acknowledgements. We thank the faculty, graduate students and staff of UOGML for their assistance in the field and identification of gorgonians. In particular we acknowledge Dr Gustav Paulay, Dr Chuck Birkeland, John Starmer, Jason Biggs, Dr Bob Thacker, Tonya Cockcroft, Rich Deloughery and Frankie Cushing. We thank Drs Anne Hoggett, Lyle Vail and staff of the LIRS for providing space and resources to conduct this research. We thank Dr Daniel Schlenk for assistance at LIRS. M.P.P. thanks Dr Phil Alderslade and his family for accommodation in Darwin, Australia, and for a course in gorgonian taxonomy. Finally, we thank Drs Rocky de Nys and Peter Steinberg for space and resources at the University of New South Wales. This manuscript benefited greatly from the comments of Dr Steve Pennings, Dr Bonnie Avery, Gary O. Laun and 2 anonymous reviewers. This research was supported by a NSF grant to M.S. (OCE-9528570), a University of Mississippi Faculty Research Award to M.S., a Lerner Grey Award to M.P.P. and a Lizard Island Augmentative Grant to M.P.P. This is contribution no. 439 of the UOGML.

\section{LITERATURE CITED}

Bakus GJ (1981) Chemical defense mechanisms and fish feeding behavior in the Great Barrier Reef, Australia. Science 211:497-499

Bakus GJ, Green G (1974) Toxicity in sponges and holothurians: a geographic pattern. Science 185:951-953

Becerro MA, Paul VJ, Starmer J (1998) Intracolonial variation in chemical defenses of the sponge Cacospongia sp. and its consequences on generalist fish predators and the specialist nudibranch Glossodoris pallida. Mar Ecol Prog Ser 168:187-196

Bolser RC, Hay ME (1996) Are tropical plants better defended? Palatability and defenses of temperate versus tropical seaweeds. Ecology 77:2269-2286

Chen CC, Chang KH (1991) Gorgonacea (Coelenterata: Anthozoa: Octocorallia) of southern Taiwan. Bull Inst Zool Acad Sin 30:149-182

Coll JC, Sammarco PW (1988) The role of chemical ecology in the chemical ecology of marine invertebrates. A meeting ground for biologists and chemists. Proc 6th Int Coral Reef Symp, Australia 1:167-173

Cronin G, Hay ME, Fenical W, Lindquist N (1995) Distribution, density and sequestration of host chemical defenses by the specialist nudibranch Tritonia hamnerorum found at high densities on the sea fan Gorgonia ventalina. Mar Ecol Prog Ser 119:177-189

Cronin G, Paul VJ, Hay ME, Fenical W (1997) Are tropical herbivores more resistant than temperate herbivores to seaweed chemical defenses? Diterpenoid metabolites from Dictyota acutiloba as feeding deterrents for tropical versus temperate fishes and urchins. J Chem Ecol 23:289-302

Faulkner DJ (1999) Marine natural products. Nat Prod Rep 16:155-198

Fenical W, Pawlik JR (1991) Defensive properties of secondary metabolites from the Caribbean gorgonian coral Erythropodium caribaeorum. Mar Ecol Prog Ser 75:1-8

Grassoff M (1999) The shallow water gorgonians of New Caledonia and adjacent islands (Coelenterata: Octocorallia). Senckenberg Biol 78:1-245

Green G (1977) Ecology of toxicity in marine sponges. Mar Biol 40:207-215

Harvell CD, Fenical W (1989) Chemical and structural defenses of Caribbean gorgonians (Pseudopterogorgia spp.): intracolony localization of defense. Limnol Oceanogr 34: 382-389

Harvell CD, Suchanek TH (1987) Partial predation on tropical gorgonians by Cyphoma gibbosum (Gastropoda). Mar Ecol Prog Ser 38:37-44

Harvell CD, Fenical W, Greene CH (1988) Chemical and structural defenses of Caribbean gorgonians (Pseudopterogorgia spp.). I. Development of an in situ feeding assay. Mar Ecol Prog Ser 49:287-294

Harvell CD, Fenical W, Roussis V, Ruesink JL, Griggs CC, Greene $\mathrm{CH}$ (1993) Local and geographic variation in the defensive chemistry of a West Indian gorgonian coral (Briareum asbestinum). Mar Ecol Prog Ser 93:165-173

Harvell CD, West JM, Griggs CH (1996) Chemical defense of embryos and larvae of a West Indian gorgonian coral, Briareum asbestinum. Invertebr Reprod Dev 30:239-246

Hay ME (1996) Marine chemical ecology: what's known and what's next? J Exp Mar Biol Ecol 200:103-134

Karentz D, Dunlap WC, Bosch I (1997) Temporal and spatial occurrence of UV-absorbing mycosporine-like amino acids in tissues of the Antarctic sea urchin Sterechinus neumayeri during springtime ozone depletion. Mar Biol 129: $343-353$ 
Kim K, Harvell CD, Kim PD, Smith GW, Merkel SM (2000) Fungal disease resistance of Caribbean sea fan corals (Gorgonia spp.). Mar Biol 136:259-267

Kinzie RA III (1970) The ecology of the gorgonians (Cnidaria: Octocorallia) of Discovery Bay, Jamaica. Doctoral dissertation, Yale University, New Haven

Koehl MAR (1982) Mechanical design of spicule-reinforced connective tissue: stiffness. J Exp Biol 98:239-267

Lasker HR (1985) Prey preferences and browsing pressure of the butterflyfish Chaetodon capistratus on Caribbean gorgonians. Mar Ecol Prog Ser 21:213-220

Lasker HR, Coffroth MA (1988) Temporal and spatial variability among grazers: variability in the distribution of the gastropod Cyphoma gibbosum on octocorals. Mar Ecol Prog Ser 43:285-295

Lewis JC, Von Wallis E (1991) The function of sclerites in gorgonians (Coelenterata, Octocorallia). Biol Bull 181:275-288

Paul VJ, Van Alstyne KL (1988) Chemical defense and chemical variation in some tropical Pacific species of Halimeda (Halimedaceae: Chlorophyta). Coral Reefs 6:263-269

Pavia H, Aberg P (1996) Spatial variation in polyphenolic content of Ascophyllum nodosum (Fucales, Phaeophyta). Hydrobiologia 326/327:199-203

Pawlik JR, Fenical W (1992) Chemical defense of Pterogorgia anceps, a Caribbean gorgonian coral. Mar Ecol Prog Ser 87:183-188

Pawlik JR, Burch MT, Fenical W (1987) Patterns of chemical defense among Caribbean gorgonian corals: a preliminary survey. J Exp Mar Biol Ecol 108:55-66

Pennings SC, Siska EL, Bertness MD (in press) Latitudinal differences in plant palatability in Atlantic coast salt marshes. Ecology

Ruesink JL, Harvell CD (1990) Specialist predation on the Caribbean gorgonian Plexaurella spp. by Cyphoma signatum (Gastropoda). Mar Ecol Prog Ser 65:265-272

Sammarco PW (1996) Comments on coral reef regeneration, bioerosion, biogeography and chemical ecology: future directions. J Exp Mar Biol Ecol 200:135-168

Slattery M (1999) Fungal pathogenesis of the sea fan Gorgonia ventalina: direct and indirect consequences. Chemoecology 9:397-104

Slattery M, McClintock JB, Heine JN (1995) Chemical defenses in Antarctic soft corals: evidence for antifouling compounds. J Exp Mar Biol Ecol 190:61-77

Sokal RR, Rohlf FJ (1981) Biometry. The principle and practice of statistics in biological research, 2nd edn. WH Freeman \& Company, New York

Steinberg PD (1989) Biogeographical variation in brown algal polyphenolics and other secondary metabolites: comparison between temperate Australasia and North America. Oecologia 78:373-382

Editorial responsibility: Joseph Pawlik (Contributing Editor), Wilmington, North Carolina, USA
Steinberg PD (1992) Geographical variation in the interaction between marine herbivores and brown algal secondary metabolites. In: Paul VJ (ed) Ecological roles for marine secondary metabolites. Comstock Publishing Associates, Ithaca, p 51-92

Steinberg PD, Van Altena IA (1992) Tolerance of marine invertebrate herbivores to brown algal phlorotannins in temperate Australasia. Ecol Monogr 62:189-222

Szmant-Froelich A (1974) Structure, iodination and growth of the axial skeletons of Muricea californica and M. fruticosa (Coelentrata: Gorgonacea). Mar Biol 27:299-306

Targett NM, Coen LD, Boettcher AA (1992) Biogeographic comparisons on marine algal polyphenolics: evidence against a latitudinal trend. Oecologia 89:464-471

Thresher RE (1991) Geographic variability in the ecology of coral reef fishes: evidence, evolution and possible interactions. In: Sale PF (ed) The ecology of fishes on coral reefs. Academic Press, San Diego, p 401-436

Van Alstyne KL, Paul VJ (1990) The biogeography of polyphenolic compounds in marine macroalgae: temperate brown algal defenses deter feeding by tropical herbivorous fishes. Oecologia 84:158-163

Van Alstyne KL, Paul VJ (1992) Chemical and structural defenses in the sea fan Gorgonia ventalina: effects against generalist and specialist predators. Coral Reefs 11: 155-159

Van Alstyne KL, Wylie CR, Paul VJ (1994) Antipredator defenses in tropical Pacific soft corals (Coelenterata: Alcyonacea). II. The relative importance of chemical and structural defenses in three species of Sinularia. J Exp Mar Biol Ecol 178:17-34

Van Alstyne KL, McCarthy JJ III, Hustead CL, Duggins DO (1999) Geographic variation in polyphenolic levels of northeastern Pacific kelps and rockweeds. Mar Biol 133: 371-379

Vrolijk NH, Targett NM (1992) Biotransformation enzymes in Cyphoma gibbosum (Gastropoda: Ovulidae): implications for detoxification of gorgonian allelochemicals. Mar Ecol Prog Ser 88:237-246

West JM (1997) Plasticity in the sclerites of a gorgonian coral: tests of water motion, light level and damage cues. Biol Bull 192:279-289

West JM (1998) The dual role of sclerites in a gorgonian coral: conflicting functions of support and defense. Evol Ecol 12:803-821

West JM, Harvell CD, Walls AM (1993) Morphological plasticity in a gorgonian coral (Briareum asbestinum) over a depth cline. Mar Ecol Prog Ser 94:61-69

Yoshioka PM, Yoshioka BB (1989) A multispecies, multiscale analysis of spatial pattern and its application to a shallowwater gorgonian community. Mar Ecol Prog Ser 54:257-264

Submitted: April 17, 2000; Accepted: August 15, 2000

Proofs received from author(s): November 8, 2000 